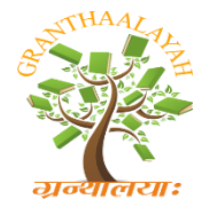

INTERNATIONAL JOURNAL OF RESEARCH GRANTHAALAYAH A knowledge Repository

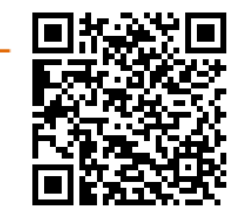

Management

\title{
DEALING WITH DUAL CAREER COUPLES: A TOOL FOR ACCEPTING AND MAKING INTERNATIONAL ASSIGNMENTS EFFECTIVE
}

\author{
Gabriel Dwomoh $^{* 1}$, Asiamah Yeboah ${ }^{2}$, Evelyn Owusu Frempong ${ }^{3}$ \\ ${ }^{* 1}$ Institute of Entrepreneurship and Enterprise Development, Kumasi Technical University, \\ Ghana \\ ${ }^{2}$ Department of Marketing, Kumasi Technical University, Ghana \\ ${ }^{3}$ Department of Management and General Studies, Christian Service University College, Ghana
}

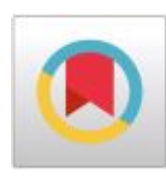

DOI: https://doi.org/10.29121/granthaalayah.v5.i6.2017.2015

\begin{abstract}
The study seeks to explore existing literature on how MNCs are dealing with dual career couples for international assignees to accept international assignment and what these MNCs have not been able to provide so that contribution can be made to the existing literature. The study was exploratory research where the contributions of various authors were assessed to determine if dual career couples pose a threat for international assignees to accept international assignment. The exploration reveals that MNCs need to deal with issues associated with dual career couples since it contribute significantly to the rejection of international assignments. There are various strategies MNCs adopt in order to entice the international assignee's spouse to give his or her blessing to the international assignment and mainly among them captured in the literature are providing a lump sum payment for the trailing spouse, inter-firm networking, assisting the trailing spouse to find job in the host country, engaging in reciprocal arrangement with other MNCs to find job for the trailing spouse in the host country and providing career support in order to make the trailing spouse skills, knowledge and abilities relevant to the host country job market. The study identified two strategies that could be used to deal with dual career couples which were not captured in the literature and these are the active involvement of the expatriate spouses in the recruitment and selection process and the use of virtual assignments by relying on the availability of technology for international assignments.
\end{abstract}

Keywords: Dual Career Couples; MNCs; International Assignment; Spouse; Expatriate.

Cite This Article: Gabriel Dwomoh, Asiamah Yeboah, and Evelyn Owusu Frempong. (2017). "DEALING WITH DUAL CAREER COUPLES: A TOOL FOR ACCEPTING AND MAKING INTERNATIONAL ASSIGNMENTS EFFECTIVE." International Journal of Research Granthaalayah, 5(6), 181-188. https://doi.org/10.29121/granthaalayah.v5.i6.2017.2015. 


\section{Introduction}

Current studies mention the significance of the spouse (and family) with reference to international assignment success (Bhaskar-Shrinivas et al., 2005, Caligiuri et al., 1998, Lazarova et al., 2010; Shaffer et al., 1999; Takeuchi et al., 2002, Takeuchi, 2010, Van 2011). The rise in dual career couples, along with other family-related issues make people immobile. Most proposed international assignees tend to reject international assignment because of family concerns whilst others reject because the partner of the international assignee will lose his or her job if the international assignee accepts the international assignment. This means the Multinational Corporation needs to deal with the career of the spouse as well as the international assignee. According to Tharenou (2003) and Dupuis et al. (2008), the willingness of the family of proposed international assignee to relocate has a positive influence on expatriate employees' willingness to accept international assignments. This assertion is also supported by Gillian (1996) that the reason behind potential expatriates reluctance to accept future international assignment is due to family problems encountered during the earlier international assignment. A significant number of studies revealed that one of the major reasons why expatriates succeed during international assignment is not only dealing with the expatriate adjustment itself but also the adjustment of the spouse of the expatriate (Caligiuri et al. 1998; Fukuda \& Chu 1994; Shaffer \& Harrison 2001). Fukuda and Chu (1994) also added that the major reason most international assignments fail is as a result of failure to deal with spousal adjustment.

From the literature of Scott (2011), research has shown that over $30 \%$ of international assignments fail because of dual-career issues. Multinational Corporations (MNCs) are also failing to attract the best talent for overseas assignments since up to $50 \%$ of proposed international assignees are just not willing to consider relocation because of the potential loss of income of their partner. According to Meier (2010), between 65 to 85 per cent of the employees on long-term assignment have an accompanying partner and 40 to 60 per cent of these partners were employed prior to the assignment but vast majority of them cannot find a job in the new location. These findings pose a question as to whether accepting international assignment makes the assignee together with the couple financially worse off. If MNCs cannot provide financial and non-financial resources that are at par available to couples at the home country, then really international assignment should be seen as punitive measures put in place to bring hardship to parent or third country nationals. This is in line with the findings of Harvey, Napier and Moeller (2009) who were of the view that dual career families are more resistant to undertaking expatriate assignments primarily due to the difficulties associated with the trailing spouse not being able to find a job overseas and the potential net financial loss for the couple. The Brookfield Global Relocation Trend Survey 2010 also states that apart from family issues that force expatriates to turn down international assignment, the career of the spouse was seen as the second main reason why expatriates refuse to honour international assignments. Again with their survey in 2012, they reported that about $46 \%$ of international assignees sampled reported partner resistance to an international assignment as the major family related challenge. One cannot deny this resistance to be attributed to many different reasons such as social ties, quality of life and career aspirations. To the researchers, the most prominent one is career aspirations as $73 \%$ of the sampled international assignees rated the partner's career as a critical or highly important expatriation challenge which may form the basis for refusing to accept international assignment. Considering the results of this survey, it means MNCs should not only look at the proposed 
international assignee when making international assignment decisions but the spouse should also be considered in such decisions. Accepting international assignment is more of sacrificing for your company and as such it should be reciprocated by the company concerned (Sebastian 2013).

According to Expatica HR Survey which was conducted in 2009, dual career couples are concerned primarily about the loss of a second income and as such are not willing to accept international assignment if these two sources of income both from the expatriate and the trailing spouse cannot be replicated abroad. Based on their survey, respondents reported that employees' reluctance to accept international assignments hinges on financial aspects which are loss of a second income and pension continuity. In the same survey, it was found out that although a wide range of support is given to dual career couples before and during assignment, repatriation support is limited thereby making the expatriate and the spouse financially worse-off upon returning to their home country.

Though many proposed expatriates may reject international assignments because of dual career issues, those who end up accepting these international assignments sometimes fail if dual career issues are not tackled by the Multinational Corporation. This is in line with a survey by Permits Foundation which reported that $21 \%$ of the organizations sampled for their study found out that failure to deal with dual career couple issues is the main cause of abysmal performance of their international assignees. When an international assignee fails in international assignment, there are numerous costs the organization incurs and as such one begins to raise issues on loss of return on investment. For instance, in a survey conducted by Ernst and Young in 2011, 85\% of international assignees return home earlier than planned. Again, 15\% return prematurely and this is seen as cost considering the investment made by the company.

The problem of selected expatriates not accepting international assignments is not only based on the fact that the spouse will lose the job at the home country but can also be attributed to problem of adjustment when both the expatriate and the spouse are repatriated to the home country. This assertion is in line with the research conducted by Harvey (1997) who found out that dual career couples have relatively consistent concerns and expectations prior to expatriation and upon repatriation to their home country. Again Harvey and Wiese (1998) posited that for proposed international assignees to accept international assignment, it is important for the spouse/partners to be aware of any assistance the Multinational Corporation will provide in job finding when repatriated and whether they will be able to return to a lateral or promoted job and comparable income. This puts the international human resource manager not only looking at things that need to put in place prior or during the international assignment but when the international assignee together with the spouse is repatriated.

The above literature points to the fact dual career couples and how MNCs handle it can have serious effect on the acceptance and success of international assignment. It is therefore necessary for us to look at the various strategies MNCs are adapting to deal with dual career couples and what can be done to make it more effective. According to Cole and McNulty (2011) there has not been a significant research on dealing with expatriate's spouse before, during and after international assignment and this is probably due to the fact that human resource managers are under estimating the importance of the spouse and therefore see no reason to draw out 
programmes effectively targeting at them. It is therefore important for us to look at the existing literature on how MNCs are dealing with dual career couples for international assignees to accept international assignment and what these MNCs have not been able to provide so that we can contribute to the existing literature. .

\section{Methodology for the Study}

The main objective of the study is to find out if dual career couple issues pose a threat for acceptance and successful completion of international assignment and what strategies Multinational Corporations are putting in place to tackle this problem. In achieving this objective, the study was based on exploratory research whereby the researchers extensively explored if the available literature supports the fact that dual career couples pose a threat for the acceptance and successful completion of international assignment. In all twenty different authors were looked at based on their research findings on issues of dual career couples and international assignment.

Having looked at these various authors and their research findings on the above issue, the researchers continued by looking at programs and strategies MNCs are putting in place to tackle dual career issues to make international assignments lucrative based on existing literature. In all eleven different authors based on their research findings were looked at to determine the available programs and strategies put in place by MNCs to deal with dual career couples to make it appealing for assignees to accept and complete international assignments.

The study concluded by looking at programs and strategies that are missing in MNCs policies in dealing with dual career couples so that arguments can be made for such inclusion in the available literature.

\section{Programs and Strategies for Dealing with Dual Career Couples}

Mohr and Klein (2004) supported by Kupka and Cathro (2007) were of the view that for a spouse to follow the expatriate on international assignment, the spouse has to resign from his/her job and abandon a potential career, which can impact on the expatriation success. To the writers, the prevalent problem faced by dual career couples in international assignments is the difficulty for the partner to find a job in the host country. Because of this, MNCs have recognized the importance of dealing with the challenges of dual career couples but the question is what policies and programmes are they putting in place to pave the way for spouses to give their blessing for partners to accept international assignment? The Brookfield Global Relocation Trend Survey 2010 cited language training, work permit sponsorship, assistance with education, lump sum allowance for spousal support, career planning assistance, employment search assistance in the host country for spouse and reimbursement for career enhancement activities as among the top strategies used by MNCs to get selected international assignees to accept international assignment. Dowling, Festing and Engle (2013) could not agree more than what was contained in the Brookfield report as the authors cited inter-firm networking, job-hunting assistance, intrafirm employment and on-assignment career support as among the strategies international firms use to entice expatriate spouses to allow their partners accept international assignment. 
Bhaskar-Shrinivas et al. (2005) in their research findings which were corroborated by Takeuchi et al. (2007) found a positive correlation between trailing spouse adjustment and expatriate adjustment. This means that for an international assignee to accept international assignment there is a need for MNCs to deal with cultural and environmental shocks as well as differences in expectation of the trailing spouse. Lauring and Jan (2010) commenting on how MNCs can deal with the challenges of dual career couples used an ethnographic approach to study the behaviors of a group of women expatriates in Saudi Arabia and identified a number of social strategies such as the creation of networks and alliances that was used to develop and support their husbands' careers. Looking at this strategy for dealing with challenges of dual career couples, it is obvious that such networks and alliances can only work if there is support from other MNCs who are willing to provide assistance to the trailing spouse usually in a reciprocal manner. Lack of cooperation and trust will render this strategy of dealing with dual career couples ineffective.

Pellico and Stroh (1997) in their research also pointed out that in most proposed international assignments, trailing spouses are not allowed to work because of work permits and visa limitations. In dealing with this challenge, most MNCs arrange for work permits, provide training that will remove language barriers as well as assistance in gaining qualification that will make the trailing spouse relevant in the host country job market. Harvey (2009) also commented on the need for MNCs to deal with the psychological trauma of the expatriate's partner that are usually transferred to the expatriate and his or her family as a result of the trailing spouse losing his or her cherished job which cannot be obtained in the host country. Dealing with psychological trauma of the spouse involves MNCs setting up counselling unit within the parent Human Resource Unit and preparing the mind of the expatriate's partner to give his or her blessings to the international assignment.

The use of adjustment phases of international assignments propounded by Black, Gregersen and Mendenhall (1992) can be a useful tool to conscientise the mind of the spouse before accompanying the expatriate to the host country. This involves explaining to the spouse that there are four phases (honeymoon, cultural shock, adjustment and mastery) the expatriate's spouse will go through before finally he or she adjusts in the new environment. Though many MNCs do apply this tool but they limit its application to the selected international assignee thereby ignoring the spouse. It is still important to remember that the willingness of the expatriate's spouse to sacrifice his or her job and accompany the international assignee in a new environment has a strong correlation with the acceptance and success of getting the selected international assignee to accept the international assignment. In light of this, MNCs should apply the tool in a holistic manner rather than applying it to only the international assignee.

Aswathappa and Dash (2008) in adding their voice to the management of dual career couples pointed out that the responsibility of the management should not be left to only the MNC but the expatriate together with the spouse can also assist. For jobs especially in the tertiary institutions were lecturers and other senior members are entitle to sabbatical leave which ranges from one to two years, the trailing spouse can ask for such a leave from his or her organization and accompany the international assignee to the host country. In this way, the trailing spouse still maintains his or her job at the home country and less financial hardships are encountered after repatriation. Though this strategy recommended by the authors is very good, it can only be applied in limited circumstances. In most organizations, sabbatical leave is granted once in 
every six to ten years and if the expatriate spouse has not worked continuously for this number of years, he or she may not be to enjoy such privilege.

\section{Gaps identified in Literature}

International recruitment and selection is a process and when it ends it should be able to deal with all the anxieties that will make the international assignee and his or her spouse reject the international assignment. Though various authors have identified ways of dealing with the challenges of dual career couples when it comes to international assignments, what is missing and most international human resource practitioners have not concentrated much on is the involvement of the expatriate spouse in the recruitment and selection process. MNCs need to involve expatriates spouse in the selection process which interview plays a key role. During such interview, spouses should be tested on their knowledge of the host country proposed for the international assignment and their expectations from the MNC so that sacrificing their jobs in the home country will not bring warfare between the expatriate and the partner. Indeed, expatriates spouse expectation and knowledge of host country should form part of the selection process during such interview. Gradually, two MNCs that have recognized the importance of involving expatriates spouse in the selection process are Ford and Exxon. These two MNCs conduct spouse and family members' assessment in the area of flexibility, patience and adaptability in the host country. Such policy is very good but there is little research as to how MNCs can adopt it to get the commitment of expatriate spouse and his or her family in assisting the expatriate to achieve the objective of the international assignment.

Another area which literature tend to be missing but more research can be done in order to solve the problem of dual career couples is how MNCs can make effective use of virtual and commuter assignments. Such assignments do not require the international assignee spouse to sacrifice his or her job in the home country since most of the time the assignee is in the home country. With the continuous improvement in technology, virtual international assignments can be effective without the physical presence of the international assignee.

\section{Conclusion}

The main aim that underlined the study was to explore literature on dual career couple issues and if it poses a threat for the acceptance and successful completion of international assignment and what strategies multinational companies are putting in place to tackle this problem. Literature available points to the fact that most selected international assignee tend to reject international assignment because of family related issues of which the job of the spouse plays a crucial role if MNCs cannot compensate for the loss of job of the expatriate's spouse. From the research, available literature points to the fact that what MNCs are doing to deal with the challenges associated with dual career couples centers on providing a lump sum payment for the trailing spouse, inter-firm networking, assisting the trailing spouse to find job in the host country, engaging in reciprocal arrangement with other MNCs to find job for the trailing spouse in the host country and providing career support in order to make the trailing spouse skills, knowledge and abilities relevant to the host country job market. MNCs need to carefully look at these strategies and programmes and adopt them depending on their strength and situation in order to achieve the objective of the international assignment. 


\section{Recommendation for Future Research}

Though various attempts have been made by various authors based on the available literature to deal with challenges associated with dual career couples, there is little research on how MNCs can draw spouses in the recruitment and selection process before the right international assignee is selected. Dealing with dual career couple should not be post recruitment and selection issue but it should form part of the process before the right international assignee is selected. Whilst this is a good way of dealing with issues of dual career couples, there is a need for research to be conducted in terms of its implementation in order to make it effective. In light of this, research on the topic; 'involving expatriates spouse in recruitment and selection process for making international assignments effective' is recommended for future research.

Again with the continuous improvement in technology, MNCs can execute international assignments without necessarily having the physical presence of the international assignee in the host country. The problem is that how can these MNCs capitalize on the availability of technology to make virtual assignments effective as a way of dealing with the challenges associated with dual career couples? Research on the topic; 'the use of ICT in virtual assignments to avoid family related challenges associated with international assignments' is also recommended for future research so that MNCs can adopt it effectively for international assignments without sending the expatriate to the proposed host country.

\section{References}

[1] Aswathappa, K. and Dash, S. (2008), International Human Resource Management, New Delphi, McGraw-Hill Publishing Limited

[2] Bhaskar-Shrinivas, P., et.al (2005). Input-based and time-based models of international adjustment: meta-analytic evidence and theoretical extensions. Academy of Management Journal, 48 (2), 257-81

[3] Black, J.S., Gregersen, H.B., and Mendenhall, M.E. (1992). 'Toward a theoretical framework of repatriation adjustment', Journal of International Business Studies, 23(4), 737-760

[4] Brookfield Global Relocation Services (2010), Global Relocation Trends Survey Report, USA

[5] Brookfield Global Relocation Services (2012). Global Relocation Trends Survey Report, USA

[6] Caligiuri, P.M., et.al (1998). Testing a Theoretical Model for Examining the Relationship between Family Adjustment and Expatriates' Work Adjustment. Journal of Applied Psychology, 83(4): 598-614

[7] Cole, N. D., and McNulty, Y. (2011). Why do Female Expatriates 'Fit-In' better than Males? An Analysis of Self-Transcendence and Socio-Cultural Adjustment, Cross Cultural Management: An International Journal. 18(2), 144-164.

[8] Dowling, P. J., Festing, M. and Engle, A. D. (2013). International Human Resource Management, 6th Ed, South-Western Publishing

[9] Dupuis, M.J. et.al (2008), 'Gender, family ties, and international mobility: cultural distance matters', The International Journal of Human Resource Management, 19(2), 274-295.

[10] Ernst and Young (2011). International Mobility and Dual Career Survey of International Employers, Permits Foundation.

[11] Expatica HR Survey (2009). Supporting dual career couples on assignment, Expatica HR

[12] Fukuda, K and Chu, P. (1994). Wrestling with expatriate family problems: Japanese experiences in East Asia, International Studies of Management and Organization, 24:36-47

[13] Gillian, F. (1996), 'Heck no - we won't go', Personnel Journal, 75(3), 37-43. 
[14] Harvey, M. (1997), Dual-Career Expatriates: Expectations, Adjustment and Satisfaction with International Relocation, Journal of International Business Studies, 28(3), 627-658

[15] Harvey, M., and Wiese, D. (1998), 'Global dual-career couple mentoring: a phase model approach', Human Resource Planning, 21(2), 33-48

[16] Harvey, M., Napier, N., Moeller, M. (2009). Interpreting dual career couples' family life-cycles: Identifying strategic windows of global career opportunity, Research and practice in human resource management, 17(2), 14-35.

[17] Kupka, B., Everett, A. M., and Cathro, V. (2008). Home alone and often unprepared intercultural communication training for expatriated partners in German MNCs, The International Journal of Human Resource Management, 19(10), 1765-1791

[18] Lauring, J., and Jan S. (2010). The Supportive Expatriate Spouse: An Ethnographic Study of Spouse Involvement in Expatriate Careers, International Business Review, 19(1), 59-69.

[19] Lazarova, M., et.al (2010). Eludicating the positive side of the work-family interface in international assignments: a model of expatriate work and family performance. Academy of Management Review, 35(1), 93-117.

[20] Meier, O. (2010). Dual Career Expatriates, Mercer, London

[21] Mohr A., Klein S. (2004). Exploring the adjustment of American expatriate spouses in Germany, International Journal of Human Resource Management, 15 (7), 1189-1206.

[22] Pellico, M.T., Stroh, L.K. (1997). Spousal assistance programs: an integral component of the international assignment, in Aycan, Z. (ed.), New Approaches to Employee Management, Vol. 4, JAI Press, Greenwich, CT, 227-43

[23] Sebastian, R (2013), Dual Career Challenges: What Can Companies Do?, IESE Business School, University of Navarra.

[24] Shaffer, M.A., et.al (1999). Dimensions, Determinants, and Differences in the Expatriate's Adjustment Process, Journal of International Business Studies, 30(3), 557-81

[25] Shaffer, M.A., and Harrison, D.A. (2001). Forgotten Partners of International Assignments: Development and Test of a Model of Spouse Adjustment, Journal of Applied Psychology, 86(2), 238-54.

[26] Scott L. (2011). The challenges of international assignments for the Dual Career Couple, Houston International HR Roundtable, LLC

[27] Takeuchi R., et.al (2002). Antecedents and consequences of the perceived adjustment of Japanese expatriates in the USA, International Journal of Human Resource Management, 13 (8), 12241244

[28] Takeuchi, R., et.al (2007). Nonlinear influences of stressors on general adjustment: The case of Japanese expatriates and their spouses. Journal of International Business Studies, 38, 928-943.

[29] Takeuchi, R. (2010). A critical review of expatriate adjustment research through a multiple stakeholder view: progress, emerging trends, and prospects. Journal of Management, 4: 10401064

[30] Tharenou, P. (2003), 'The initial development of receptivity to work abroad: Self initiated international work opportunities in young graduate employees', Journal of Occupational and Organizational Psychology, 76, 489-515

[31] Van Erp, K. P. J. M. (2011). When worlds collide: the role of justice, conflict and personality for expatriate couples'adjustment, University of Groningen

*Corresponding author.

E-mail address: gabdwumoo@yahoo.com 